Chinese Journal of Organic Chemistry

\title{
二苯并噻吩的合成研究进展
}

\author{
程辉成 ${ }^{a}$ 郭鹏虎 ${ }^{a}$ 陈 冰 ${ }^{a}$ 姚嘉伟 ${ }^{a}$ 马姣丽 $*, a$ \\ 胡炜杰 ${ }^{a}$ 纪红兵*, $a, b$ \\ ( ${ }^{a}$ 广东石油化工学院化学学院 广东高校果蔬加工与諚藏工程技术开发中心 广东茂名 525000) \\ ( ${ }^{b}$ 中山大学化学学院 精细化工研究院 广州 510275)
}

\begin{abstract}
摘要 二苯并噻吩类化合物广泛用于有机光敏化合物、染料、液晶、导电聚合物和药物合成等领域, 至今为止已经涌 现出大量的合成方法. 当前报道的二苯并噻吩及其衍生物的合成方法主要通过 $\mathrm{C}-\mathrm{S}$ 键和 $\mathrm{C}-\mathrm{C}$ 键的环化以实现在二苯 并噻吩结构中含硫五元杂环的构造. 此外, 通过噻吩及其衍生物和四碳合成子的环化形成苯环也是构建二苯并噻吩的 重要手段, 以及通过酸、碱和其他非金属的作用形成分子内 $\mathrm{C}-\mathrm{S}$ 键也可以实现二苯并噻吩的合成. 然而, 这些方法大 多数受依赖于预功能化的起始原料或多步程序的限制. 在过去的几十年中, 过渡金属催化的偶联反应逐渐成为一种有 力的方法用于二苯并噻吩的构建. 在这个微型综述中, 结合直到 2020 年二苯并噻吩的最新研究进展, 将广泛讨论二苯 并噻吩合成的环化方法.
\end{abstract}

关键词＼cjkstart含硫杂环化合物；二苯并噻吩类化合物；合成反应；过渡金属催化；无过渡金属催化

\section{Recent Advances in the Synthesis of Dibenzothiophenes}

\author{
Cheng, Huicheng ${ }^{a}$ \\ Guo, Penghu ${ }^{a}$ \\ Chen, Bing ${ }^{a}$ \\ Yao, Jiawei ${ }^{a}$ \\ Ma, Jiaoli*,a \\ $\mathrm{Hu}, \mathrm{Weijie}^{a}$ \\ Ji, Hongbing *,a,b \\ ( ${ }^{a}$ Development Center of Technology for Fruit \& Vegetables Storage and Processing Engineering, College of Chemistry, \\ Guangdong University of Petrochemical Technology, Maoming, Guangdong 525000) \\ $\left({ }^{b}\right.$ Fine Chemical Industry Research Institute, School of Chemistry, Sun Yat-sen University, Guangzhou 510275)
}

\begin{abstract}
Dibenzothiophenes are widely used in organic photoactive compounds, dyes, liquid crystals, conducting polymers, pharmaceuticals and other fields. Until now, various approaches for their synthesis have been well-documented, among which the cyclization of the $\mathrm{C}-\mathrm{S}$ bond and the $\mathrm{C}-\mathrm{C}$ bond to achieve the construction of a five-membered sulfur heterocycle in the dibenzothiophene structure is most widely reported. Besides, it also can be realized by the formation of a benzene ring in a dibenzothiophene structure through cyclization of thiophene/its derivatives and a four-carbon synthon. The formation of intramolecular $\mathrm{C}-\mathrm{S}$ bonds by acids, bases and other non-metallic species is another alternative for dibenzothiophenes synthesis. However, most of these methods are limited by their reliance on prefunctionalization of starting materials or multistep procedures. Over the past decades, transition-metal-catalyzed coupling reactions have emerged as a powerful method for the construction of dibenzothiophenes. In this mini review, based on the latest research progress on dibenzothiophene synthesis until 2020, we briefly discuss the following types of cyclization methods.
\end{abstract}

Keywords $S$-heterocyclic compound; dibenzothiophenes; synthesis; transition metal catalysis; transition-metal-free

\section{Introduction}

As versatile sulfur-containing heterocyclic molecules, dibenzothiophenes usually play key roles in many important organic compounds including photoactive com- pounds, dyes, liquid crystals, conducting polymers and pharmaceuticals (Figure 1). ${ }^{[1-3]}$ For example, sulfur-containing conjugated benzoheterocyclic molecules, benzo[1,2$\left.b: 5,4-b^{\prime}\right]$ bis $[1]$ benzothiophene (BBBT) and naphtho[2,3$b]$-naphtho[ $\left[2^{\prime}, 3^{\prime}: 4,5\right]$ thieno $[2,3-d]$ thiophene (DNTT) are

\footnotetext{
* Corresponding author. E-mail: xiaojiaoli.good@163.com; jihb@mail.sysu.edu.cn

Received June 18, 2020; revised July 26, 2020; published online August 18, 2020.

Project supported by the National Natural Science Foundation of China (Nos. 21938001, 21961160741), the Science and Technology Plan of Maoming City (Nos. 2019401, 20200581), and the Guangdong University of Petrochemical Technology (Nos. 2012gczxB001, 517152, 517136, 2019rc053, 2019rc047).

国家自然科学基金(Nos. 21938001，21961160741)、茂名市科技计划(Nos. 2019401，2020581)、广东石油化工学院基金(Nos. 2012gczxB001，517152， $517136,2019 \mathrm{rc} 053,2019 \mathrm{rc} 047$ ) 资助项目.
} 
promising candidates for thin film transistor materials fabrication. 8-Dibenzothiophen-4-yl-2-morpholin-4-yl-chromen-4-one (NU7441) and 13-dihydro-13-[6-amino- $\beta$ - $d$ glucopyranosyl]-5H,13H-benzo[b]thienyl[2,3-a]pyrrolo[3,4-c]carbazole-5,7(6H)-dione (BMS 251873) can effectively inhibit DNA-dependent protein kinase and fluoroindolocarbazole topoisomerase I, respectively.

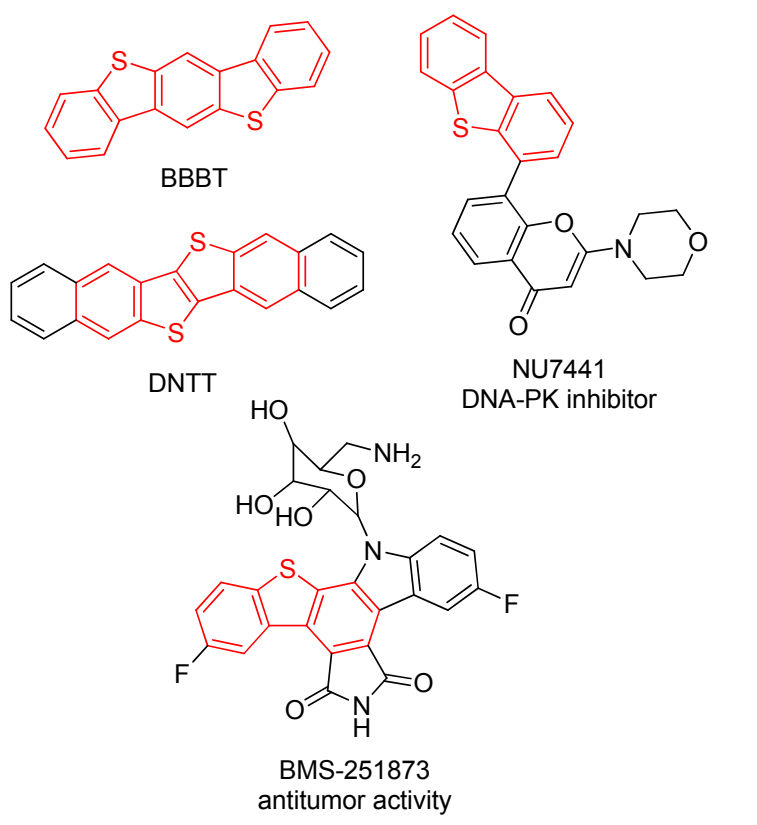

Figure 1 Representative of benzo-fused thiophenes as pharmaceuticals and organic electronics

Dibenzothiophene that was initially identified as an isomer of diphenyl sulfide by mistake was first synthesized by Stenhouse in 1870 through heating diphenyl sulfide in the presence of iron nails. ${ }^{[4-5]}$ Later in 1938, Gilman et al. ${ }^{[6]}$ reported the preparation of dibenzothiophenes, using biphenyl and sulfur as raw materials and $\mathrm{AlCl}_{3}$ as catalyst. Although the synthesis method and the purification procedures are complicated, the dibenzothiophenes synthesis has continuously received intense interest.

Due to the vital function of thiophene motif in diverse organic compounds of different fields, a number of methods for the facile and efficient synthesis of dibenzothiophenes have been established in recent years (Figure 2). Most of these methods for the synthesis of dibenzothiophene and its derivatives are through the cyclization of $\mathrm{C}-\mathrm{S}$ bond and $\mathrm{C}-\mathrm{C}$ bond generating a five-membered sulfur heterocycle (Figure 2, type $\mathrm{A} \sim \mathrm{C}$ ). Recently, the cyclization of thiophene or its derivatives and four-carbon synthon to form a benzene ring and then dibenzothiophene has been reported (Figure 2, type D). In this review, the following types of cyclization methods together with the latest research progress of dibenzothiophene and its derivatives synthesis until early 2020 are briefly discussed.

\section{Transition-metal-free $\mathrm{C}-\mathrm{S}$ bond forma- tion for dibenzothiophenes}

\subsection{C-X Cleavage for dibenzothiophenes synthesis}

In 2006, Fananas group ${ }^{[7]}$ found that the treatment of 2-fluorophenyl 2-iodophenyl thioether with 3.3 equiv. of $t$-BuLi, which further reacted with selected electrophiles, gave rise to functionalized dibenzothiophene derivatives (Scheme 1). The process involves an anionic cyclization on a benzyne-tethered aryllithium intermediate.

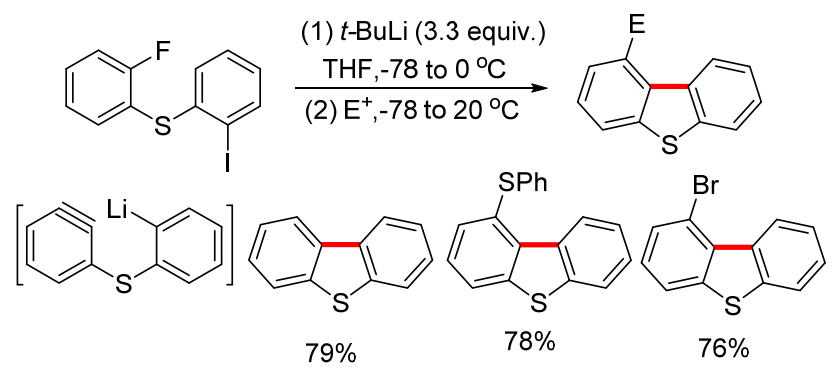

Scheme 1 Anionic cyclization of benzyne-tethered aryllithiums for dibenzothiophenes

Four years later, Knochel group ${ }^{[8]}$ developed a novel cyclization reaction leading to various S-containing heterocycles compounds. This method undergoes a molecular cyclization of dithiocarbamates readily prepared by a palladium catalyzed cross-coupling method to form dibenzothiophenes (Scheme 2). With moderate to high yields, this reaction offers dibenzothiophene derivatives with high regioselectivity and broad substrate scopes.

After Knochel group's work, Nielsen and coworkers ${ }^{[9]}$ designed a three-step synthesis of dibenzothiophene by palladium catalyzed $\mathrm{C}-\mathrm{C}$ and $\mathrm{C}-\mathrm{S}$ coupling. First, substituted biphenyl compound is synthesized by palladium catalyzed Suzuki-Miyaura coupling reaction of halogen substituted benzene and 2-fluorophenylboronic acid. Then, palladium catalyzed $\mathrm{C}-\mathrm{S}$ coupling of the substituted biphenyl compound with ethyl mercaptopropionate affords ethyl 3-((2'-fluoro-[1,1'-biphenyl]-2-yl)thio)propanoates. Finally, the deprotection of the intermediates generates the in situ $\mathrm{C}-\mathrm{S}$ cyclization products dibenzothiophenes at $150{ }^{\circ} \mathrm{C}$ in the presence of potassium $t$-butoxide (Scheme 3 ). Furthermore, during the above processes, the functional group of the reactants is well compatible and regioselective. However, the substrate synthesis undergoes palladi-
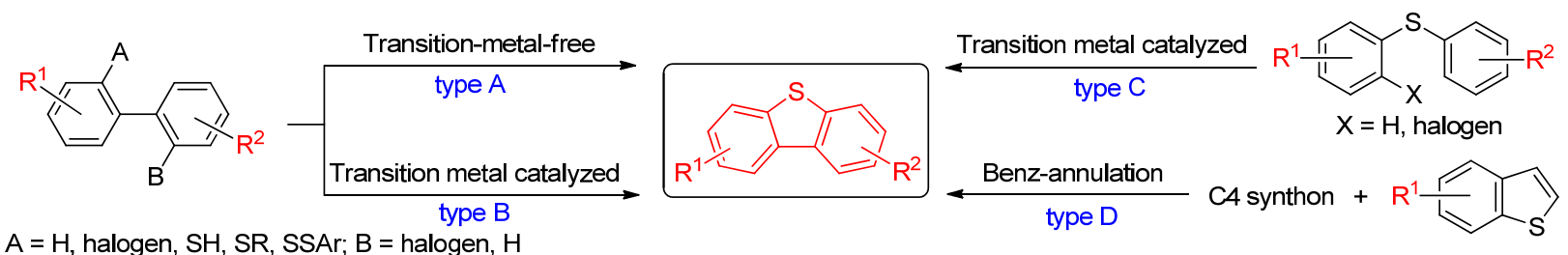

Figure 2 Means in the construction of dibenzothiophene 


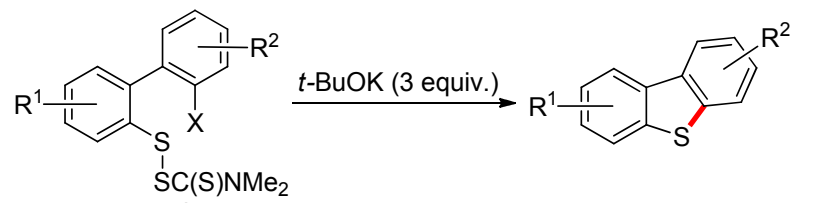

diate $\mathbf{C}$ with the help of base.
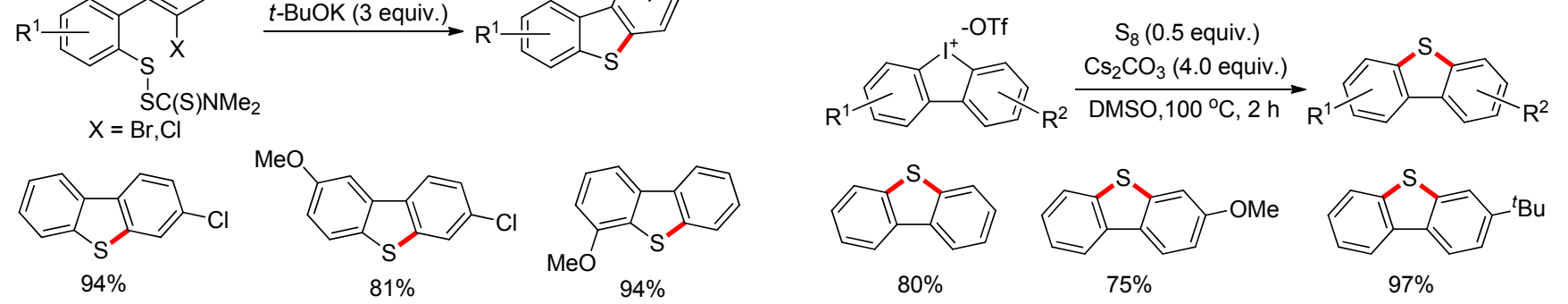

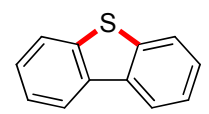

$80 \%$

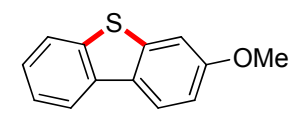

$75 \%$

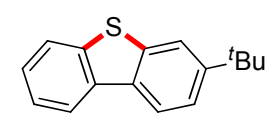

$97 \%$

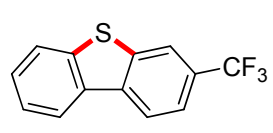

$99 \%$

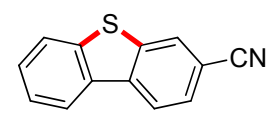

$72 \%$

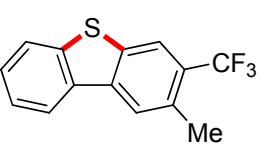

$93 \%$

Scheme 2 Ring-closure for synthesis of dibenzothiophenes

$$
\text { (1) }
$$

$95 \%$<smiles>Fc1ccc2sc3ccccc3c2c1</smiles>

$94 \%$

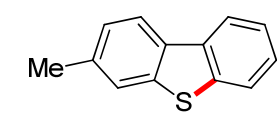

$92 \%$

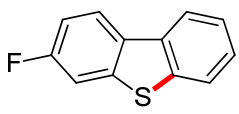

$94 \%$

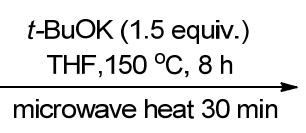

microwave heat $30 \mathrm{~min}$<smiles>[R]c1ccc2c(c1)sc1ccccc12</smiles>

Scheme 3 Intramolecular $\mathrm{C}-\mathrm{S}$ coupling cyclization of biphenyl thioether esters for dibenzothiophenes synthesis

um-catalyzed carbon-carbon and carbon-sulfur bond formations, resulting in low efficiency.

In 2016, Jiang group reported ${ }^{[10]}$ another method for dibenzothiophene synthesis by iodine-sulfur atoms exchange without transition metal assistance (Scheme 4). It is worth mentioning that this method can also be applied to the synthesis of five-membered selenium heterocycles by selenium-iodine exchange, dibenzo six-membered, seven-membered and eight-membered ring heterocyclic compounds. This proposed mechanism is shown in Figure 3. The cycle of iodine-sulfur atoms exchange is initiated with the interaction of elemental sulfur and base, generating trisulfur radical anion at $100{ }^{\circ} \mathrm{C}$. Then, the exchange of trisulfur radical anion with the anion from diaryliodonium salt 1a leads to intermediate A. Subsequently, the cleavage of $\mathrm{C}_{\mathrm{Ar}}$ - I produces aryl radical intermediate $\mathbf{B}$, which transfers from trisulfur to aryl group. The radical is further coupled with another trisulfur radical anion with expulsion of intermediate $\mathbf{C}$. Finally, the product dibenzothiophene can be derived from the intramolecular $\mathrm{S}_{\mathrm{N}} 2$ cyclization of intermediate $\mathbf{D}$, which is from the dissociation of interme-

Scheme 4 Radical/anion-mediated sulfur-iodine exchange for dibenzothiophenes synthesis

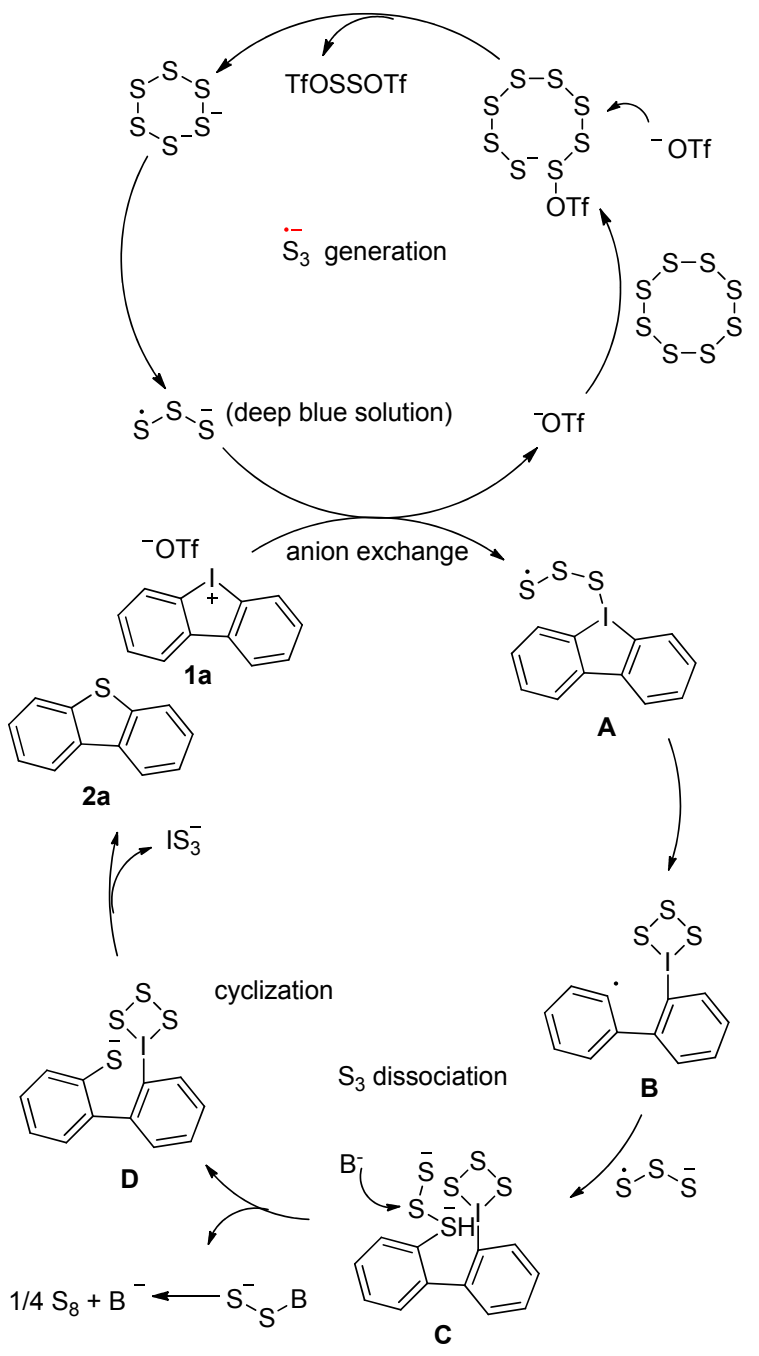

Figure 3 Proposed mechanism for radical/anion-mediated sulfur-iodine exchange

\section{2 $\mathrm{C}-\mathrm{H}$ functionalization for dibenzothiophenes}

In 2012, Patel group ${ }^{[11]}$ reported a convenient and efficient method for the synthesis of unsymmetrical dibenzothiophene derivatives (Scheme 5). With the aid of sulfuric acid, intramolecular cyclization of biaryl sulfoxides 
produces dibenzothiophenes under low temperature with very short reaction time. Interestingly, this method gives access to a substituent at every position of dibenzothiophene. For example, 1-subsituted dibenzothiophene, which is difficult to obtain by direct substitution reaction on dibenzothiophene, can be easily prepared by this method.

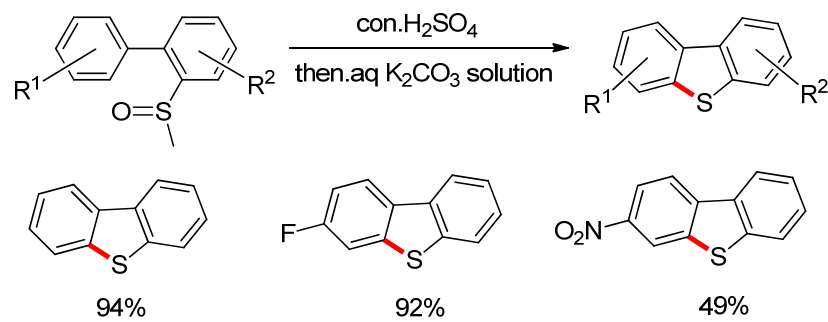

Scheme 5 Acid-mediated intramolecular cyclization of biaryl methyl sulfoxides for dibenzothiophenes

Recently, Sakai group ${ }^{[12]}$ discovered that the iodinemediated cyclization of 2-biarylyl disulfides with various substituents gives direct access to dibenzothiophenes (Scheme 6). This protocol features transition-metal-free conditions and inexpensive and eco-friendly $\mathrm{I}_{2}$ as an oxidant. However, the cyclization reaction of substrates with electron-withdrawing substituent groups was limited by the low yield. The reaction pathway proceeds through oxidative cleavage of $\mathrm{S}-\mathrm{S}$ bond of 2-biphenylyl disulfide by $\mathrm{I}_{2}$ and subsequent $\mathrm{C}-\mathrm{S}$ bond formation by $\mathrm{S}_{\mathrm{E}} \mathrm{Ar}$ (Figure 4 ). First, aryl $\mathrm{S}-\mathrm{I}$ intermediate $\mathbf{A}$ is formed via the oxidative cleavage of the $\mathrm{S}-\mathrm{S}$ bond of 2-biphenylyl disulfide by $\mathrm{I}_{2}$. Then, the intramolecular $S_{E} A r$ to the highly reactive $S-I$ bond produces tricyclic intermediate B. Finally, the product dibenzothiophene results from deprotonation of intermediate $\mathbf{B}$ by a base.

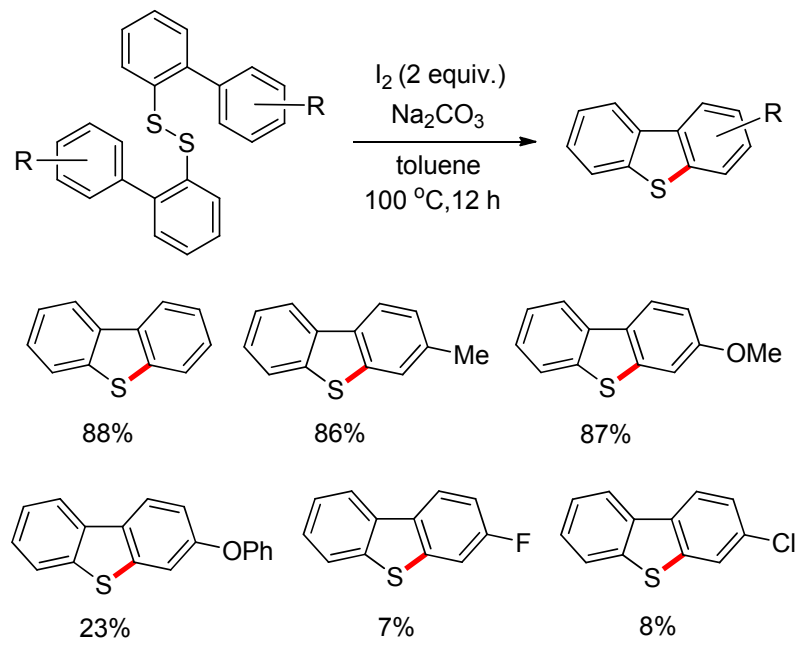

Scheme 6 Iodine-mediated cyclization of 2-biarylyl disulfides for dibenzothiophenes

\section{Transition metal catalyzed $\mathrm{C}-\mathrm{S}$ bond formation for dibenzothiophenes}

In $2010, \mathrm{Xi}$ group ${ }^{[13]}$ reported that the $\mathrm{Cu}$-catalyzed Ullmann reaction of 2,2'-iodo substituted biphenyl with
$\mathrm{K}_{2} \mathrm{~S}$ for dibenzothiophene at $140{ }^{\circ} \mathrm{C}$ (Scheme 7). In 2013, they ${ }^{[14]}$ continued designing another one-pot strategy for the synthesis of dibenzothiophene with high efficiency. This method can be successfully applied to the construction of cyclic sulfur-containing molecular structure by using 2,2'-iodine-substituted biphenyl as substrate and inexpensive and readily available $\mathrm{CS}_{2}$ as sulfur source (Scheme 7).

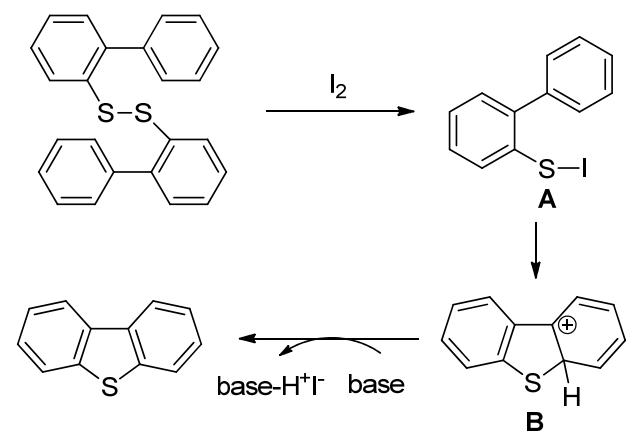

Figure 4 Proposed reaction pathway for iodine-mediated cyclization
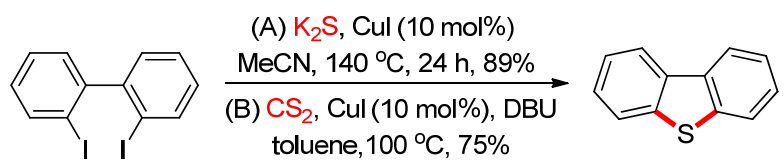

Scheme $7 \mathrm{Cu}$-catalyzed Ullmann reaction for synthesis of dibenzothiophenes

Three years later, Tobisu and coworkers ${ }^{[15]}$ developed the palladium(II)-catalyzed synthesis of dibenzothiophenes via the cleavage of $\mathrm{C}-\mathrm{H}$ and $\mathrm{C}-\mathrm{S}$ bonds (Scheme 8). Notably, the product is formed by an oxidative addition step, rather than a reductive elimination. Advantages of this new catalytic $\mathrm{C}-\mathrm{H} / \mathrm{C}-\mathrm{S}$ coupling method are absence of an external oxidant and reactive functional groups such as $\mathrm{C}-\mathrm{X}$ or $\mathrm{S}-\mathrm{H}$. The proposed mechanism for this palladium-catalyzed $\mathrm{C}-\mathrm{H} / \mathrm{C}-\mathrm{S}$ coupling is outlined in Figure 5. This cycle is initiated with the ligand exchange of $\mathrm{Pd}(\mathrm{OAc})_{2}$ with $\mathrm{ArCO}_{2} \mathrm{H}$, which regenerates the active catalytic species $\mathrm{Pd}(\mathrm{OCOAr})_{2}$. Then, the sulfur-directed cyclometallation process with $\mathrm{Pd}(\mathrm{OCOAr})_{2}$ affords palladacycle, followed by reductive elimination of $\mathbf{A}$ to afford sulfonium intermediate $\mathbf{B}$ with a dibenzosulfonium cation and an anionic $\operatorname{Pd}(0)$ fragment. Subsequently, the cleaved phenyl group of $\mathbf{B}$ with $\mathrm{ArCO}_{2} \mathrm{H}$ is released as benzene following the protonolysis of complex $\mathbf{C}$, which is formed via the oxidative addition of the $\mathrm{Ph}-\mathrm{S}$ bond in dibenzosulfonium to the $\operatorname{Pd}(0)$ center, along with the generation of D. Finally, the intermediate $\mathbf{D}$ is dissociated into dibenzothiophene and reactive $\mathrm{Pd}(\mathrm{OCOAr})_{2}$ to complete the catalytic cycle.

As an important class of high-valence organic iodine reagents, a series of polycyclic (hetero)aromatic hydrocarbons can be synthesized through diverse transformations of cyclic diaryl iodide salts. The synthesis and 


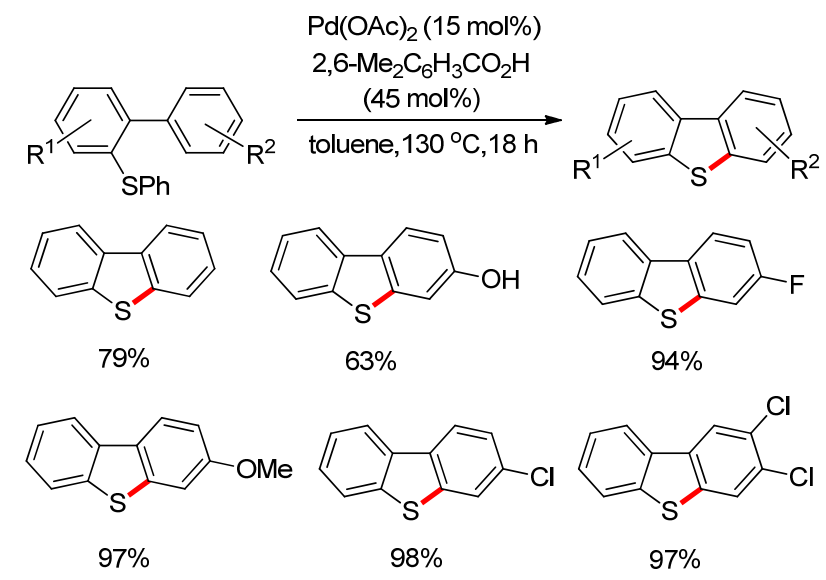

Scheme 8 Preparation of dibenzothiophene by Pd-catalyzed cleavage of $\mathrm{C}-\mathrm{S}$ and $\mathrm{C}-\mathrm{H}$ bonds

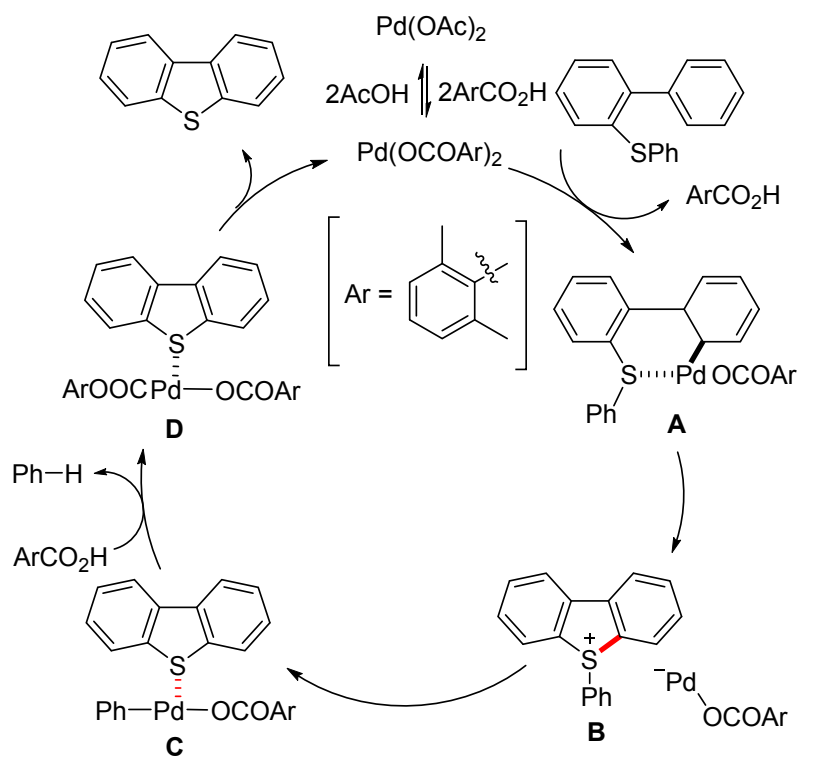

Figure 5 Proposed mechanism for Pd-catalyzed $\mathrm{C}-\mathrm{H} / \mathrm{C}-\mathrm{S}$ coupling

application of them have attracted wide attention of chemists. In 2016, Huang and coworkers ${ }^{[16]}$ reported that copper sulfate accelerated chemical conversion to recycle dual $\mathrm{C}-\mathrm{S}$ functionalization of diaryl iodide under mild conditions (Scheme 9). It is worth mentioning that this reaction can use an easily prepared triethylammonium $N$-benzyldithiocarbamate as a sulfur source.

As shown in Figure 6, a possible mechanism has been proposed for $\mathrm{Cu}$-catalyzed dual $\mathrm{C}$ (aryl) $-\mathrm{S}$ bond formation with cyclic diaryliodoniums for dibenzothiophenes synthesis. First, the oxidative addition of $\mathbf{1}$ with in situ generated $\mathrm{Cu}(\mathrm{I})$ species affords $\mathbf{A}$ (path a), after which $\mathbf{B}$ is formed via ligand exchange with dithiocarbamate and reductive elimination. Subsequently, a free radical-mediated mechanism probably occurs to give $\mathbf{2}$ (paths $b$ and c) from which the liberation of isothiocyanate results in the generation of 3. Finally, the $\mathrm{Cu}$-mediated intramolecular $\mathrm{C}-\mathrm{S}$ bond formation of $\mathbf{3}$ generates dibenzothiophene and reactive $\mathrm{Cu}(\mathrm{I})$ species to close the catalytic cycle.

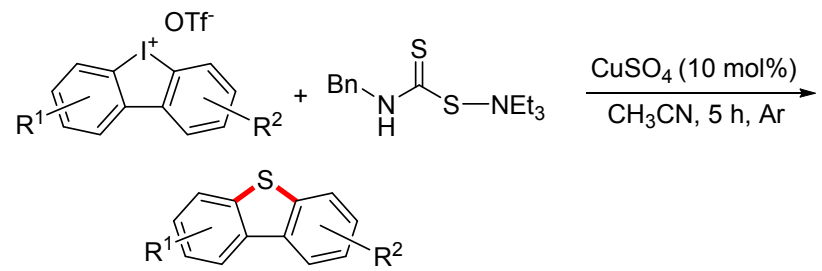<smiles>COc1ccc2c(c1)sc1ccccc12</smiles><smiles>Fc1ccc2c(c1)sc1ccccc12</smiles><smiles>Cc1ccc2c(c1)sc1cc(F)ccc12</smiles>

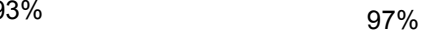<smiles>COc1ccc2c(c1)sc1cc(C#N)ccc12</smiles>

Scheme 9 Cu-catalyzed dual $\mathrm{C}(\operatorname{aryl})-\mathrm{S}$ bond formation with cyclic diaryliodoniums for dibenzothiophenes

Shimizu, Jiang and Li group also reported the synthesis of dibenzothiophene and its derivatives by way of transition metal-catalyzed sulfur-iodine exchange reaction of cyclic diaryliodonium salts. In the same year, Shimizu and coworkers $^{[17]}$ reported that copper-catalyzed double $S$-arylation of dibenzoiodotrifluoromethanesulfonate with potassium thioacetate in tetrahydrofuran (THF) or dimethyl sulfoxide (DMSO) for the synthesis of dibenzothiophenes (Scheme 10, Protocol A). In 2017, Jiang group ${ }^{[18]}$ developed a copper triflate catalyst for a sulfur-iodine exchange of cyclic diaryliodonium tetrafluoroborate with inorganic sulfur salt for dibenzoiodothiophenes (Scheme 10, Protocol B). Later, Li and coworkers ${ }^{[19]}$ designed a new method for the synthesis of dibenzothiophenes using sodium sulfide as a sulfur source and ferric chloride as a catalyst (Scheme 10, Protocol C).

In 2018, Song and coworkers ${ }^{[20]}$ designed a simple and practical Pd-catalyzed tandem reaction to construct dibenzothiophene (Scheme 11). The reaction was conducted through one-step synthesis employing commercially available $o$-bromoiodobenzene and benzenethiol or benzenethiol and $o$-bromo-benzenethiol as precursor materials to synthesize a series of dibenzothiophenes and their derivatives.

In 2018, palladium-catalyzed cyclization of 2-biphenyl disulfide was developed by Sakai group for dibenzothiophene derivatives synthesis (Scheme 12). ${ }^{[21]}$ Importantly, this reaction is highly resistant to various functional groups and does not require further addition of metal oxidants, bases or auxiliary ligands. Moreover, the method can also be applied to the preparation of dibenzoselenones. As shown in Figure 7, the reaction cycle begins with the oxidative addition of palladium dichloride to the $\mathrm{S}-\mathrm{S}$ bond of 2-biphenylyl disulfide, along with the generation of $\mathrm{Pd}(\mathrm{IV})$ species $\mathbf{A}$ that then undergoes $\mathrm{C}-\mathrm{H}$ functionalization to 


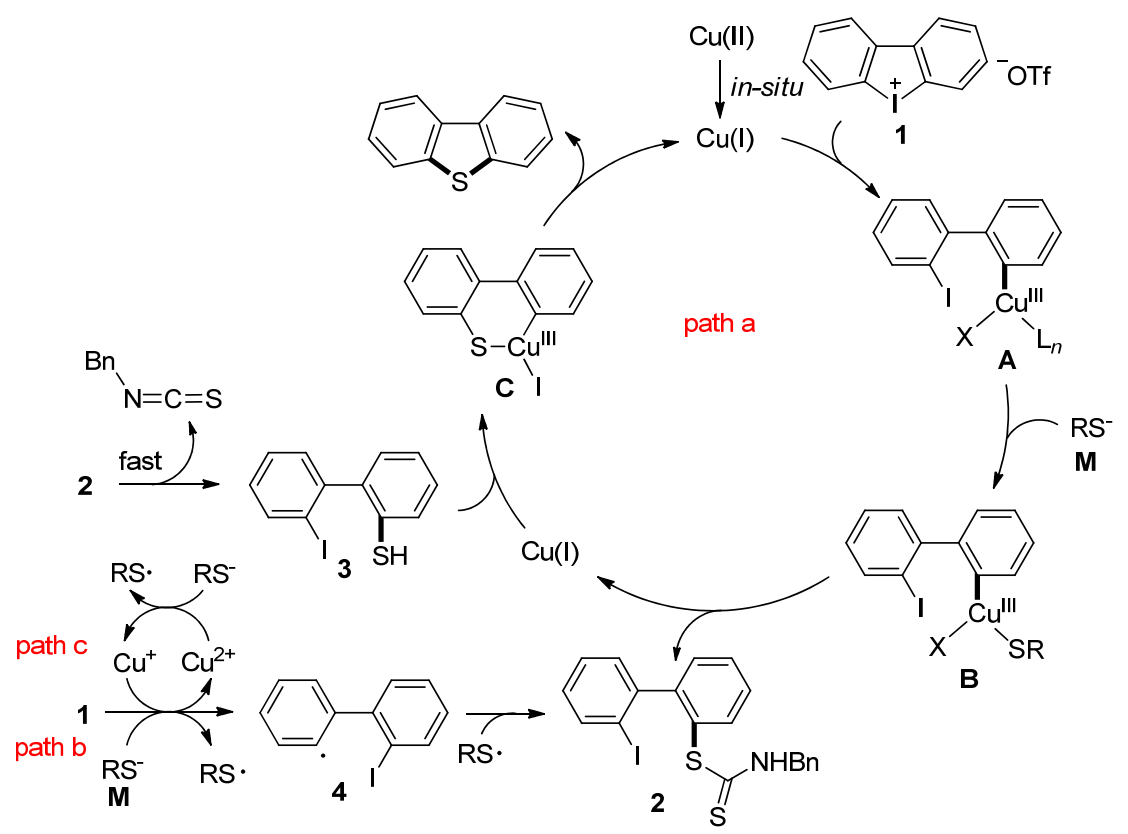

Figure 6 Proposed mechanism for $\mathrm{Cu}$ sulfur-iodine exchange with cyclic diaryliodoniums

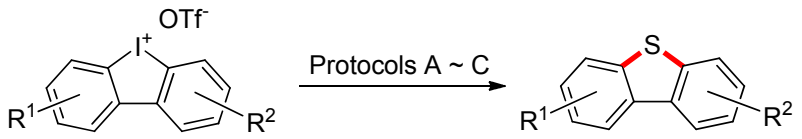

Protocol A: KSAc (2.0 equiv.), $\mathrm{CuCl}_{2}$ (4 mol\%), THF, $110^{\circ} \mathrm{C}$ (Shimizu et al.)

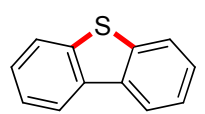

$99 \%$

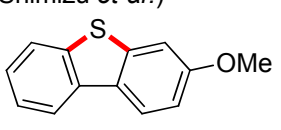

$70 \%$
$92 \%$

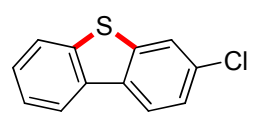

Protocol B: KSAc (2.0 equiv.), Cu(OTf $)_{2}(10 \mathrm{~mol} \%), 1,10$-phen (12 mol\%), $\mathrm{K}_{3} \mathrm{PO}_{4}$, DMSO, $100{ }^{\circ} \mathrm{C}, 6 \mathrm{~h}$ (Jiang et al.)

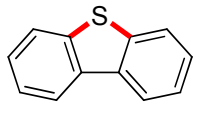

$75 \%$<smiles>COc1ccc2c(c1)sc1ccccc12</smiles>

$72 \%$

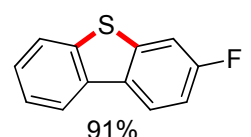

$91 \%$
Protocol C: $\mathrm{Na}_{2} \mathrm{~S} \cdot 9 \mathrm{H}_{2} \mathrm{O}, \mathrm{FeCl}_{3}(10 \mathrm{~mol} \%), \mathrm{DMSO}, 100^{\circ} \mathrm{C}$ (Li et al.)

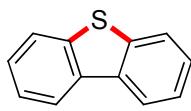

$86 \%$

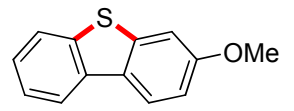

$49 \%$

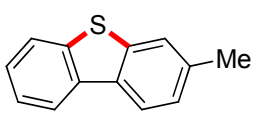

$53 \%$
Scheme $10 \mathrm{Cu}$ or Fe-catalyzed sulfur-iodine exchange for synthesis of dibenzothiophenes

form a six-membered palladacycle B. Subsequent reductive elimination of $\mathbf{B}$ gives rise to dibenzothiophene and palladium(II) complex $\mathbf{C}$. Then, the cyclization of species C generates six-membered palladacycle $\mathbf{D}$ via $\mathrm{C}-\mathrm{H}$ functionalization, which undergoes reductive elimination to give another dibenzothiophene and $\operatorname{Pd}(0)$ catalyst. Finally, the $\mathrm{Pd}(0)$ catalyst is oxidized with $\mathrm{DMSO}$ and $\mathrm{HCl}$ to regenerate a $\mathrm{Pd}(\mathrm{II})$ catalyst to complete the catalytic cycle.

In the same year, Tan and coworkers ${ }^{[22]}$ discovered palladium-catalyzed cyclization of 2-benzenethiol for the synthesis of dibenzothiophenes under $\mathrm{PdCl}_{2} / \mathrm{DMSO}$ catal-

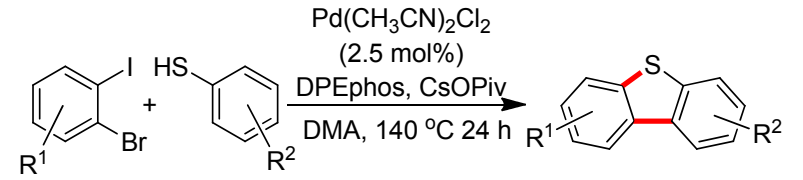<smiles>Cc1ccc2sc3ccccc3c2c1</smiles><smiles>Cc1ccc2c(c1)sc1cc(C)ccc12</smiles>

$81 \%$<smiles>Clc1ccc2sc3ccccc3c2c1</smiles>

$66 \%$

$\mathrm{Pd}\left(\mathrm{CH}_{3} \mathrm{CN}\right)_{2} \mathrm{Cl}_{2}$

$(2.5 \mathrm{~mol} \%)$

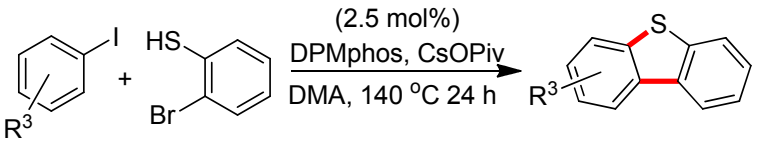

$85 \%$<smiles>c1ccc2c(c1)sc1ccccc12</smiles>

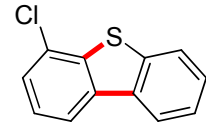

$70 \%$<smiles>Fc1ccc2sc3ccccc3c2c1</smiles>

$81 \%$
Scheme 11 Pd-catalyzed tandem reaction for the synthesis of dibenzothiophenes

ysis (Scheme 13). This highly efficient reaction with a wide range of substrates employed simple $\mathrm{PdCl}_{2} / \mathrm{DMSO}$ catalytic system in which $\mathrm{PdCl}_{2}$ is the sole metal catalyst and DMSO acts as both oxidant and solvent. Relying on simple operation and high returns, the helical dinaphothiophene and the well-known organic semiconductor dibenzo[ $\left[d, d^{\prime}\right]$ thieno[3,2- $\left.b ; 4,5-b\right]$ dithiophene (DBTDT) were efficiently synthesized by this method. Interestingly, this catalytic system can also synthesize trithiophenefuran with high degree of tension and large steric effect.

Recently, Jiang group ${ }^{[23]}$ developed a direct synthesis of sulfur-containing benzoheterocycles utilizing intramolecular $\mathrm{C}-\mathrm{H}$ sulfide reaction of thioacetate (Scheme 14). Ta- 
<smiles>[R][R]c1ccc(-c2ccccc2SSc2ccccc2-c2ccc([R])cc2)cc1</smiles>
$\underset{\mathrm{DMSO}, 120^{\circ} \mathrm{C}, 12 \mathrm{~h}}{\stackrel{\mathrm{PdCl}_{2}(5 \mathrm{~mol} \%)}{\longrightarrow}}$

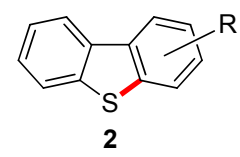

$89 \%$

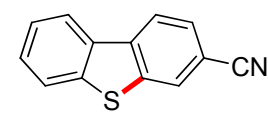

$69 \%$

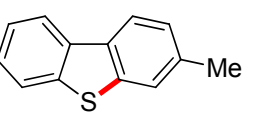

$86 \%$

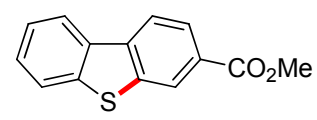

$80 \%$

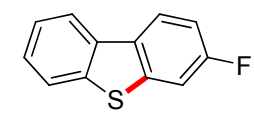

$73 \%$

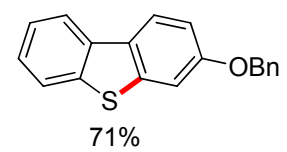

Scheme 12 Palladium(II)-catalyzed synthesis of dibenzothiophenes from 2-biphenylyl disulfides by $\mathrm{C}-\mathrm{H}$ functionalization

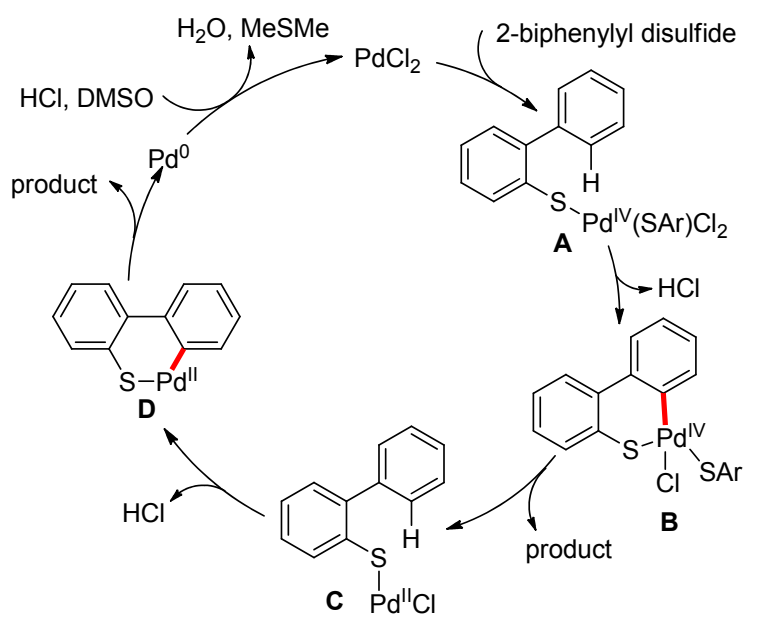

Figure 7 Proposed mechanism for palladium-catalyzed $\mathrm{C}-\mathrm{H}$ activation for dibenzothiophenes

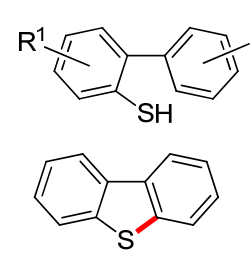

$95 \%$

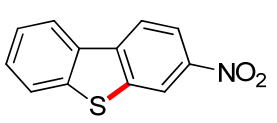

$85 \%$
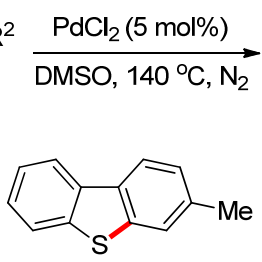

$85 \%$

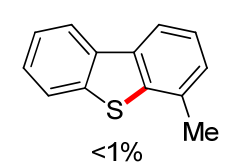

Scheme 13 Pd-catalyzed cyclization of 2-biphenylthiols to dibenzothiophenes

king advantage of this method, a variety of functional dihydrobenzothiophenes and thiobenzothiophenes are synthesized by Pd-catalyzed carbon-sulfur cyclization.

\section{Transition metal catalyzed $\mathrm{C}-\mathrm{C}$ bond formation for dibenzothiophenes}

$\mathrm{C}-\mathrm{C}$ coupling reaction via a $\mathrm{C}-\mathrm{H}$ bond activation of

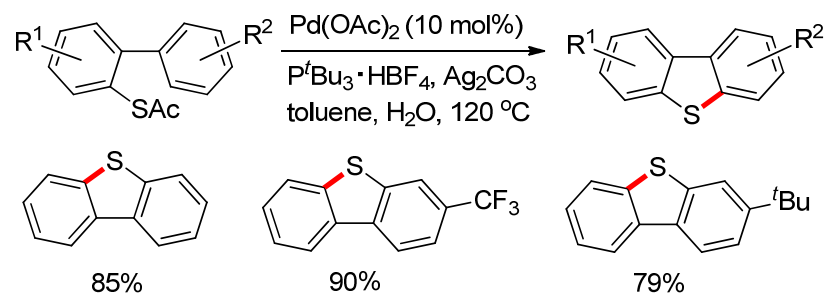

Scheme 14 Pd-catalyzed $\mathrm{C}-\mathrm{S}$ cyclization via $\mathrm{C}-\mathrm{H}$ functionalization for dibenzothiophenes

diaryl sulfides is an effective way to construct the fivemembered ring of dibenzothiophenes. This coupling reaction is generally divided into two types: the coupling of $\mathrm{C}-\mathrm{X} / \mathrm{C}-\mathrm{H}$ bond, and the oxidative dehydrogenation coupling of intramolecular $\mathrm{C}-\mathrm{H} / \mathrm{C}-\mathrm{H}$ bond.

In 2011, Antonchick group ${ }^{[24]}$ reported palladium- catalyzed double $\mathrm{C}-\mathrm{H}$ bond activation of simple benzyl phenyl sulfoxides for the synthesis of dibenzothiophenes (Scheme 15). Upon the abstraction of four hydrogen atoms, the products are formed in a cascade reaction, which is highly regioselective as a result of the strictly defined sequence of reaction. This protocol employing the palladium catalyst up to $15 \%$ molar ratio afforded various dibenzothiophene derivatives in moderate to good yields with tolerance of a wide variety of substrates. Therefore, this method provides strong innovation significance on the organic synthesis.

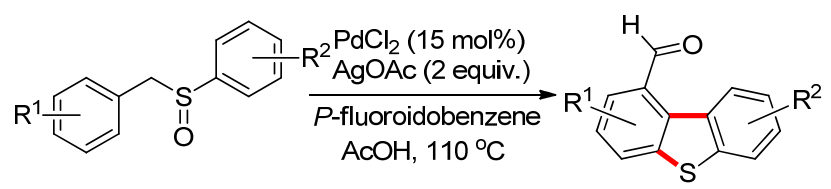<smiles>Cc1ccc(C=O)c2c1sc1ccccc12</smiles><smiles>Cc1cc(C=O)c2c(c1)sc1ccccc12</smiles><smiles>O=Cc1ccc(F)c2sc3ccccc3c12</smiles><smiles>O=Cc1ccc(Cl)c2sc3ccccc3c12</smiles><smiles>O=Cc1cccc2sc3ccc(Cl)cc3c12</smiles><smiles>O=Cc1cccc2sc3cc4ccccc4cc3c12</smiles>

Scheme 15 Palladium-catalyzed double $\mathrm{C}-\mathrm{H}$ activation directed by sulfoxides for dibenzothiophenes

This proposed mechanism of palladium-catalyzed double $\mathrm{C}-\mathrm{H}$ activation directed by sulfoxides for dibenzothiophenes synthesis is displayed in Figure 8. The cycle begins with the electrophilic attack of $\mathrm{Pd}(\mathrm{II})$, leading to the formation of bimetallic species A. Subsequently, complex $\mathbf{B}$ is formed via oxidative addition of aryl iodide which promotes the formation of species $\mathbf{C}$. Then, complex $\mathbf{C}$ undergoes first reductive elimination and $\mathrm{C}-\mathrm{H}$ activation to produce palladacycle $\mathbf{C}$ and aryl acetate. Finally, the reductive elimination leads to the formation of cyclic sul- 
foxide 2 and $\mathrm{Pd}(0)$, which is reoxidized to $\mathrm{Pd}(\mathrm{II})$ by $\mathrm{AgO}$ Ac. Pummerer rearrangement of sulfoxide 2 promoted by $\mathrm{AgOAc}$ and acetic acid, gives mercaptoaldehyde 4 . In the second cycle, palladium catalyzes directing-group-assisted intramolecular $\mathrm{C}-\mathrm{H}$ functionalization and $\mathrm{C}-\mathrm{S}$ bond formation for the synthesis of dibenzothiophenes.
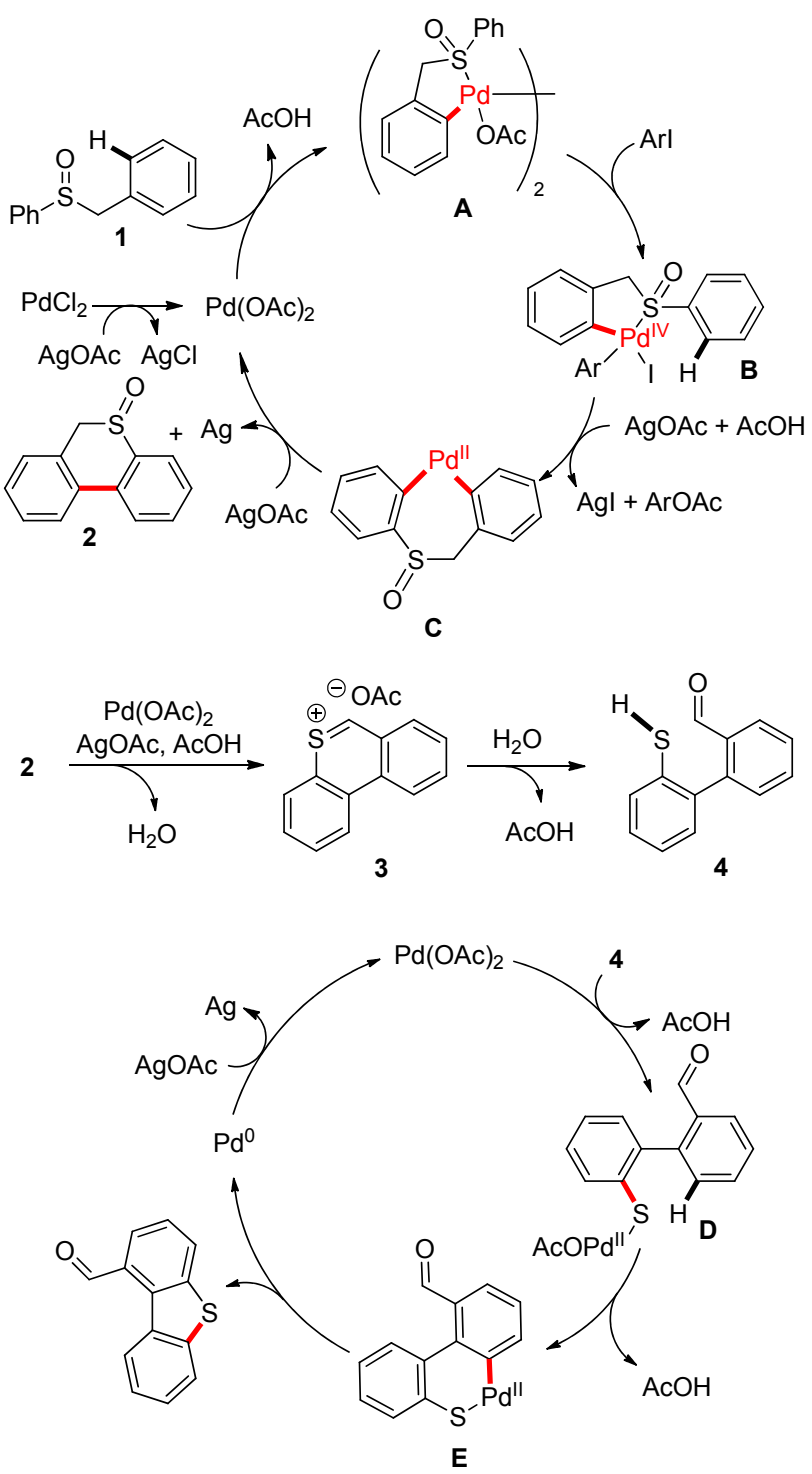

Figure 8 Proposed mechanism for palladium-catalyzed double $\mathrm{C}-\mathrm{H}$ bond activation for dibenzothiophenes

In 2014, Anbarasan group ${ }^{[25]}$ developed the palladiumcatalyzed intramolecular $\mathrm{C}-\mathrm{H}$ bond arylation of diverse unsymmetrical diaryl sulfides to construct dibenzothiophenes (Scheme 16). The precursor diaryl sulfide was synthesized by palladium-catalyzed aryl (alkyl)-thiolation of various substituted unactivated arenes with electrophilic sulfur reagents derived from succinimide. Although the reaction requires pre-synthesis of electrophilic sulfur reagents as precursor and reaction efficiency is low, it provides an alternative for the synthesis of dibenzothiophene derivatives.

Two years later, Du and coworkers ${ }^{[26]}$ reported the pal-

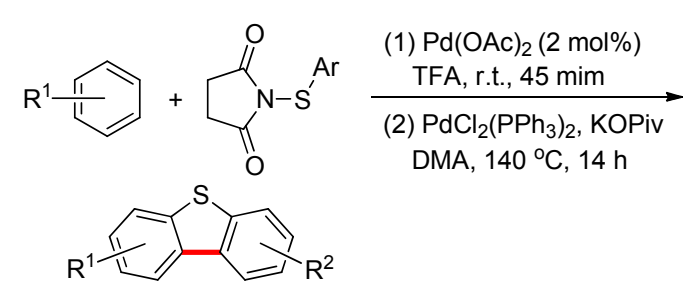<smiles>c1ccc2c(c1)sc1ccccc12</smiles>

$88 \%$<smiles>Cc1ccc2sc3ccc(C)cc3c2c1</smiles>

$85 \%$
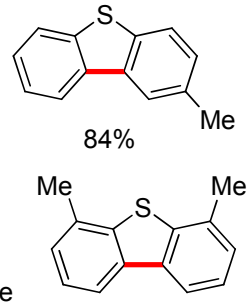

$78 \%$
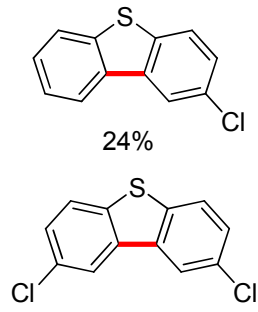

$21 \%$
Scheme 16 Pd-catalyzed $\mathrm{C}-\mathrm{S}$ coupling and intramolecular $\mathrm{C}-\mathrm{H}$ bond activation for dibenzothiophenes

ladium-catalyzed cyclization of 2-iodinated diaryl sulfide for the synthesis of dibenzothiophenes with anhydrous $\mathrm{Cu}(\mathrm{OAc})_{2}$ as an additive (Scheme 17). This protocol affords a series of dibenzothiophene derivatives in moderate to excellent yield.
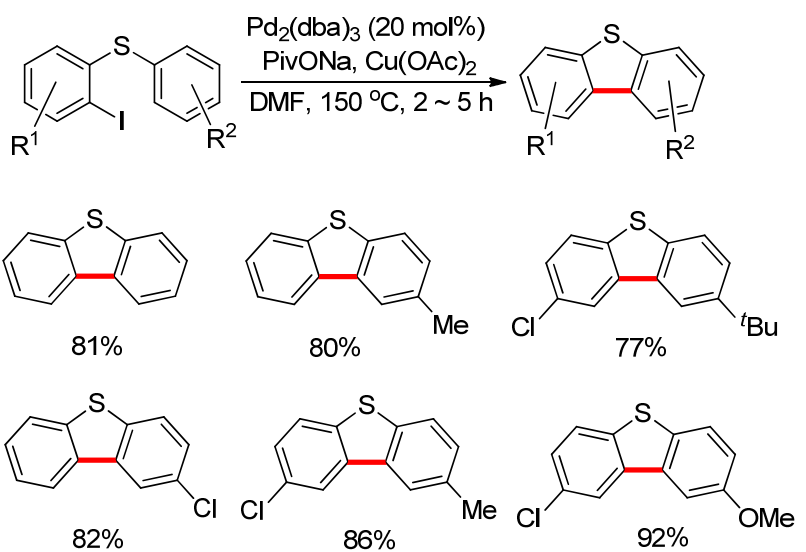

Scheme 17 Palladium-catalyzed the ring closure of 2-iodized diaryl sulfide for dibenzothiophenes

In 2014, Zhou group ${ }^{[27]}$ described a palladium-catalyzed intramolecular oxidative $\mathrm{C}-\mathrm{H} / \mathrm{C}-\mathrm{H}$ coupling of diaryl sulfides for dibenzothiophenes (Scheme 18). The reaction uses silver acetate as an oxidant and pivalic acid as a solvent to facilitate the cleavage of $\mathrm{C}-\mathrm{H}$ bond. A broad range of functional groups were well tolerated under the simple reaction conditions, and a series of dibenzothiophenes with substituents at differrent positions were obtained in moderate to good yields. A possible mechanistic pathway is illustrated in Figure 9. Initially, palladium catalyst coordinates the substrate and the close proximity activates $\mathrm{C}-\mathrm{H}$ bond to afford the intermediate $\mathbf{A}$. Then, the intramolecular $\mathrm{C}-\mathrm{H}$ cleavage of intermediate $\mathbf{A}$ generates intermediate $\mathbf{B}$, which is considered as the rate-determining step. Finally, the reductive elimination of the intermediate II provides the desired product dibenzothiophene along with $\operatorname{Pd}(0)$, which is oxidized by $\operatorname{Ag}(\mathrm{I})$ to regenerate 
the active catalytic species Pd(II) to close the cycle.<smiles>[R]c1ccc2sc3cc(-c4ccccc4)ccc3c2c1</smiles><smiles>Cc1cccc2c1sc1ccccc12</smiles>

$79 \%$<smiles>c1ccc2c(c1)sc1ccccc12</smiles>

$86 \%$
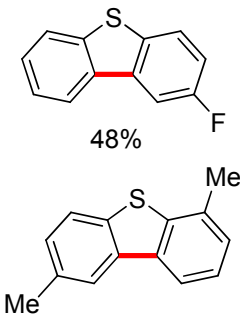

$82 \%$

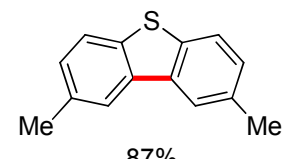

$87 \%$

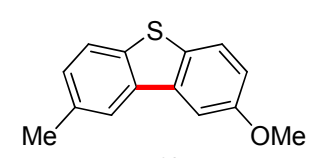

$83 \%$
Scheme 18 Pd-catalyzed intramolecular oxidative $\mathrm{C}-\mathrm{H} / \mathrm{C}-\mathrm{H}$ coupling of diaryl sulfides to construct dibenzothiophenes

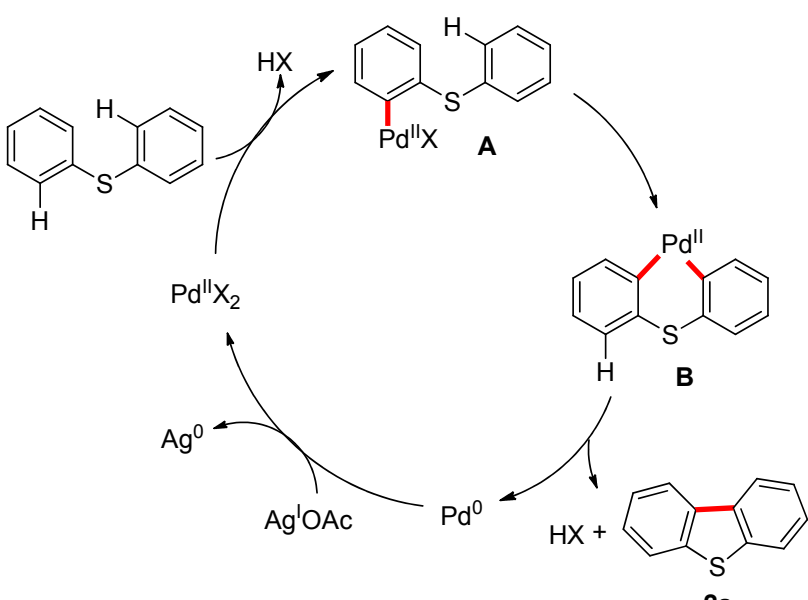

2a

Figure 9 Proposed mechanism for palladium-catalyzed intramolecular oxidative $\mathrm{C}-\mathrm{H} / \mathrm{C}-\mathrm{H}$ coupling for dibenzothiophenes

In 2015, Lin group ${ }^{[28]}$ reported rhodium-catalyzed the cyclization of diaryl sulfoxides to dibenzothiophene derivatives (Scheme 19). The reaction proceeds through an intramolecular cross-dehydrogenative-coupling reaction and subsequent deoxygenation. Unfortunately, the substrates with strong electron-withdrawing groups, such as nitro and fluoride, are poorly reactive for the process.

A possible mechanistic pathway for Rh-catalyzed sequential dehydrogenation/deoxygenation of diphenyl sulfoxide for dibenzothiophenes is proposed (Figure 10). In the first cycle, the intramolecular dehydrogenation of diphenyl sulfoxide proceeds involving the electrophilic attack of Rh(III) species to sulfoxide. Next, the second $\mathrm{C}-\mathrm{H}$ bond activation occurs to afford the formed rhodium intermediate $\mathbf{B}$, which undergoes reductive elimination to give dibenzothiophene $S$-oxide and $\mathrm{Rh}(\mathrm{I})$. This cycle II is initiated with the treatment of dibenzothiophene $S$-oxide with $\mathrm{RhOCOCF}_{3} \mathbf{C}$, which provides sulfonium ion $\mathbf{D}$ and releases carbon dioxide. Then, dibenzothiophene is formed via the attack of $\mathrm{CF}_{3}$ anion to oxygen atom of sulfonium

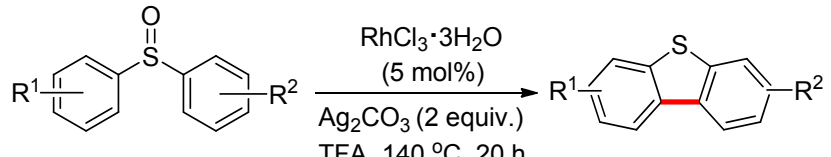<smiles>c1ccc2c(c1)sc1ccccc12</smiles>

$88 \%$<smiles>Cc1ccc2sc3ccc(C)cc3c2c1</smiles>
$85 \%$<smiles>Cc1ccc2sc3ccccc3c2c1</smiles><smiles>Cc1cccc2c1sc1c(C)cccc12</smiles>

$78 \%$<smiles>Clc1ccc2sc3ccccc3c2c1</smiles>

$24 \%$

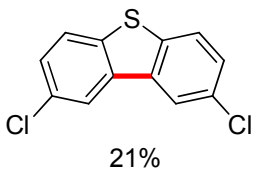

Scheme 19 Rh-catalyzed sequential dehydrogenation/deoxygenation for dibenzothiophenes

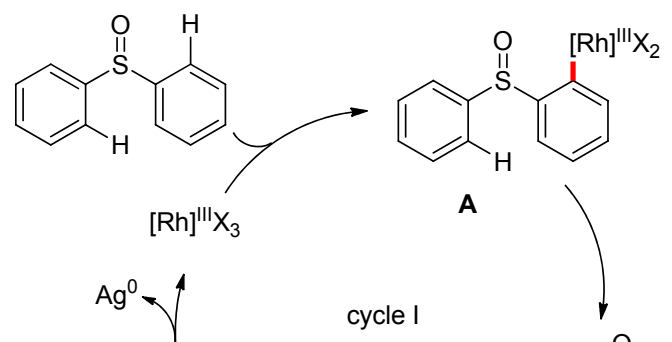<smiles>CC(C)C(C)C</smiles>
cycle I

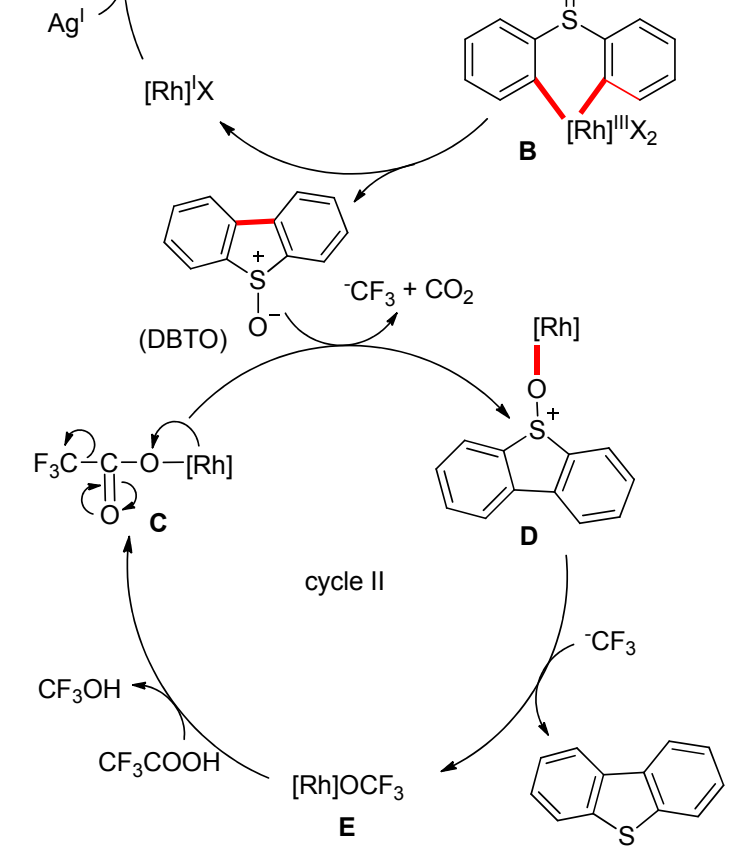

Figure 10 Proposed mechanism for Rh-catalyzed sequential dehydrogenation/deoxygenation for dibenzothiophenes

ion $\mathbf{D}$ along with $\mathrm{RhOCF}_{3}$ E. Finally, intermediate $\mathbf{E}$ transforms into the active catalytic species $\mathrm{RhOCOCF}_{3} \mathbf{C}$ to close the cycle.

\section{Constructing dibenzothiophenes from thiophene and its derivatives}

In 2014, Mohanakrishnan and coworkers ${ }^{[29]}$ synthesized 
dibenzothiophene and its derivatives by Lewis acid/ Brönsted acid-mediated cyclization (Scheme 20). 2,5-Dimethoxytetrahydrofuran was used as a four-carbon synthon to react with thiophene and benzothiophene through cyclization reaction at room temperature.

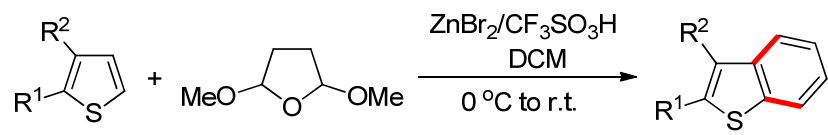

$\mathrm{R}^{1}, \mathrm{R}^{2}=\mathrm{H}, \mathrm{Br}$, alkyl, aryl, heteroaryl, 1-4-buta-1,3-dienyl,

5,6-diemthylenecyclohexa-1,3-dienyl

Scheme 20 Synthesis of dibenzothiophene by Lewis acid/ Brönsted acid mediated benz-annulation of thiophenes

In 2015, Mancini and coworkers ${ }^{[30]}$ reported the polar Diels-Alder reactions of 2- or 3-nitrobenzothiophenes with 1-methoxy-3-trimethylsiloxy-1,3-butadiene to synthesize dibenzothiophene. Normally, this cycloaddition reaction was carried out under anhydrous benzene with the assistance of microwave irradiation (Scheme 21).

Recently, Meng group ${ }^{[31]}$ developed a one-pot synthesis of dibenzothiophene and 1,4-dihydrodibenzothiophene through domino reaction (Scheme 22). The reaction is based on a readily available allyl sulfonium salt, the mild reaction conditions, and the broad substrate scope. These advantages create conditions for applications in the fields of materials and pharmaceutical science.

\section{Conclusions and perspectives}

A variety of methods for the synthesis of dibenzothiophenes and its derivatives via the $\mathrm{C}-\mathrm{S}$ bonds formation catalyzed by acids, bases or other non-metallic species have been established. However, suffering from prefunctionalization of synthesis precursors and multi-step procedures, most of these methods are neither atom-economical nor eco-friendly. Over the past decade, transition-metalcatalyzed coupling reactions have emerged as a powerful method for the construction of dibenzothiophenes. For example, palladium- and other transition-metal-catalyzed intramolecular $\mathrm{C}-\mathrm{H} / \mathrm{S}-\mathrm{H}$ and $\mathrm{C}-\mathrm{H} / \mathrm{C}-\mathrm{S}$ coupling reactions have been widely reported for synthesizing dibenzothiophenes possessing versatile functional groups at different positions. Unfortunately, these synthetic methods generally require essential additives such as metal oxidant, auxiliary ligand or base to drive and boost the desired cyclization. Therefore, our mini-review is expected to provide some inspiration on the pursuit of more economical and environmentally benign methodology without transition metal-based catalyst, which will be one of the development directions in the future for the construction of dibenzothiophenes.

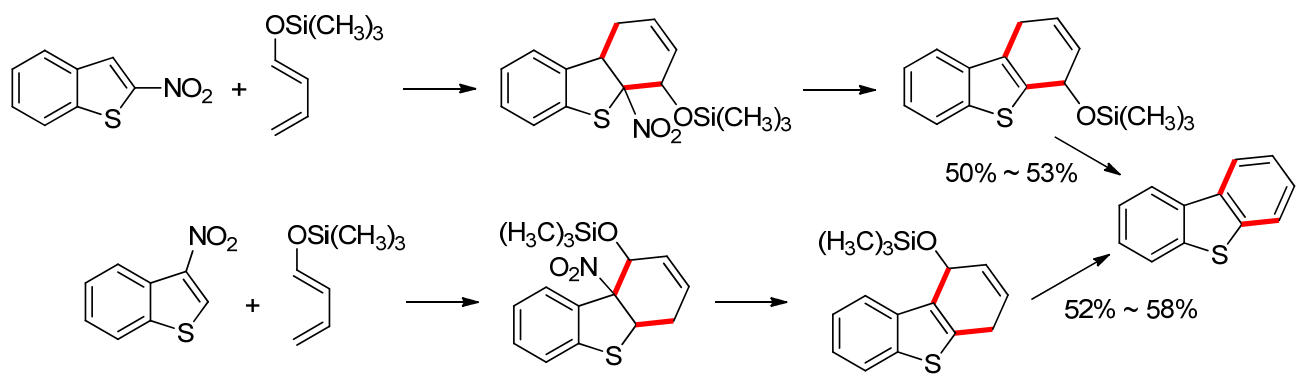

Scheme 21 Synthesis of dibenzothiophene by polar Diels-Alder reactions
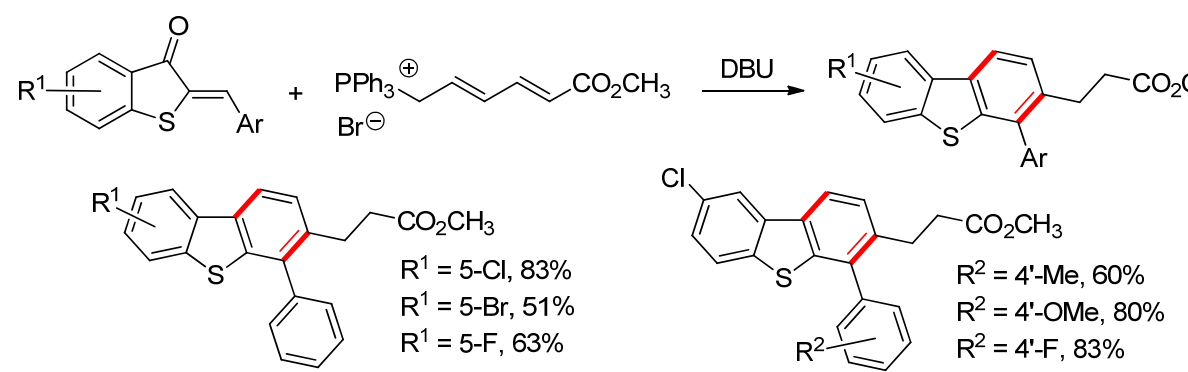

Scheme 22 Synthesis of dibenzothiophenes via allylic phosphonium salt initiated domino reactions

\section{References}

[1] (a) Yamamoto, T.; Takimiya, K. J. Am. Chem. Soc. 2007, 129, 2224. (b) Gao, J.; Li, L.; Meng, Q.; Li, R.; Jiang, H.; Li, H.; Hu, W. J. Mater. Chem. 2007, 17, 1421.

(c) Wang, Y.; Parkin, S. R.; Gierschner, J.; Watson, M. D. Org. Lett. 2008, 10, 3307 .

(d) Allard, S.; Forster, M.; Souharce, B.; Thiem, H.; Scherf, U. Angew. Chem. Int. Ed. 2008, 47, 4070.

(e) Mori, T.; Nishimura, T.; Yamamoto, T.; Doi, I.; Miyazaki, E.; Osaka, I. J. Am. Chem. Soc. 2013, 135, 13900. (f) Fukazawa, A.; Kishi, D.; Tanaka, Y.; Seki, S.; Yamaguchi, S. Angew. Chem. Int. Ed. 2013, 52, 12091

(g) Zhang, S.; Qiao, X.; Chen, Y.; Wang, Y.; Edkins, R. M.; Liu, Z.; Li, H.; Fang, Q. Org. Lett. 2014, 16, 342.

[2] Lin, K.; Ming, S.; Zhen, S.; Zhao, Y.; Lu, B.; Xu, J. Polym. Chem. 2015, 6, 4575 .

[3] (a) Ilardi, E. A.; Vitaku, E.; Njardarson, J. T. J. Med. Chem. 2014, $57,2832$.

(b) Smith, B. R.; Eastman, C. M.; Nijardarson, J. T. J. Med. Chem. 2014, 57, 9764.

(c) Feng, M.; Tang, B.; Liang, S. H.; Jiang, X. Curr. Top. Med. 
Chem. 2016, 16, 1200.

(c) Jiang, X. Sulfur Chemistry, Springer, Berlin, 2019.

(d) Wang, N.; Saidhareddy, P.; Jiang, X. Nat. Prod. Rep. 2020, 37, 246.

[4] Stenhouse, J. Liebigs Ann. Chem. 1870, 156, 332.

[5] Graebe, C. Liebigs Ann. Chem. 1874, 174, 177.

[6] Gilman, H.; Jacoby, A. J. Org. Chem. 1938, 3, 108.

[7] Sanz, R.; Fernandez, Y.; Castroviejo, M. P.; Perez, A.; Fananas, F. J. J. Org. Chem. 2006, 71, 6291 .

[8] Kienle, M.; Unsinn, A.; Knochel, P. Angew. Chem., Int. Ed. 2010, 49, 4751.

[9] Jepsen, T. H.; Larsen, M.; Jorgensen, M.; Solanko, K. A.; Bond, A. D.; Kadziola, A.; Nielsen, M. B. Eur. J. Org. Chem. 2011, 53.

[10] Wang, M.; Fan, Q.; Jiang, X. Org. Lett. 2016, 18, 5756.

[11] Pandya, V. B.; Jain, M. R.; Chaugule, B. V.; Patel, J. S.; Parmar, B. M.; Joshi, J. K.; Patel, P. R. Synth. Commun. 2012, 42, 497.

[12] Nishino, K.; Ogiwara Y.; Sakai, N. Eur. J. Org. Chem. 2017, 5892.

[13] You, W.; Yan, X.; Liao, Q.; Xi, C. Org. Lett. 2010, 12, 3930.

[14] Zhao, P.; Yin, H.; Gao, H.; Xi, C. J. Org. Chem. 2013, 78, 5001.

[15] Tobisu, M.; Masuya, Y.; Baba, K.; Chatani, N. Chem. Sci. 2016, 7, 2587.

[16] Luo, B.; Cui, Q.; Luo, H.; Hu, Y.; Huang, P.; Wen, S. Adv. Synth. Catal. 2016, 358, 2733.

[17] Shimizu, M.; Ogawa, M.; Tamagawa, T.; Shigitani, R.; Nakatani, M.; Nakano, Y. Eur. J. Org. Chem. 2016, 2785.
[18] Wang, M.; Wei, J.; Fan, Q.; Jiang, X. Chem. Commun. 2017, 53, 2918.

[19] Liu, L.; Qiang, J.; Bai, S.; Li, Y.; Li, J. Appl. Organomet. Chem. 2017, 31, 2365.

[20] Song, J.; Wu, H.; Sun, W.; Wang, S.; Sun, H.; Xiao, K.; Qian, Y.; Liu, C. A. Org. Biomol. Chem. 2018, 16, 2083.

[21] Norio, S.; Kota, N.; Yohei, O. Chem.-Eur. J. 2018, 24, 10971.

[22] Zhang, T.; Deng, G.; Li, H.; Liu, B.; Tan, Q.; Xu, B. Org. Lett. 2018, 20, 5439.

[23] Chen, S.; Wang, M.; Jiang, X. Chin. J. Chem. 2018, 36, 921.

[24] Samanta, R.; Antonchick, A. P. Angew. Chem., Int. Ed. 2011, 50, 5217.

[25] Saravanan, P.; Anbarasan, P. Org. Lett. 2014, 16, 848.

[26] Du, Z. T.; Zhang, T.; Chen, Y. F.; Ma, R. Y.; Zhou, L. N. Heterocycles 2016, 92, 1874 .

[27] Che, R.; Wu, Z.; Li, Z.; Xiang, H.; Zhou, X. Chem.-Eur. J. 2014, 20,7258 .

[28] Huang, Q.; Fu, S.; Ke, S.; Xiao, H.; Zhang, X.; Lin, S. Eur. J. Org. Chem. 2015, 6602.

[29] Rafiq, S. M.; Sivasakthikumaran, R.; Mohanakrishnan, A. K. Org. Lett. 2014, 16, 2720.

[30] Della Rosa, C. D.; Mancini, P. M. E.; Kneeteman, M. N.; Lopez Baena, A. F. L.; Suligoy, M. A.; Domingo, L. R. J. Mol. Struct. 2015, 1079, 47.

[31] Li, K.; Yu, A.; Meng, X. Org. Lett. 2018, 20, 1106. 